\title{
Gender budgeting: a vital element for ensuring sustainable development
}

\author{
Orçamento de gênero: um elemento central do \\ desenvolvimento sustentável
}

\author{
Olena Bilyk ${ }^{1}$ \\ Veronika Karkovska ${ }^{2}$ \\ Maria Khim ${ }^{3}$
}

${ }^{1}$ Doctor of Science in Public Administration, Professor, Department of Administrative and Financial Management, Lviv Polytechnic National University, Lviv, Ukraine E-mail: olena.i.bilyk@lpnu.ua

${ }^{2}$ Doctor of Science in Public Administration, Professor, Department of Administrative and Financial Management, Lviv Polytechnic National University, Lviv, Ukraine E-mail: Veronika.Y.Karkovska@Ipnu.ua

${ }^{3}$ Master's Degree in International information and management of higher educational institutions, Senior lecturer, Department of Administrative and Financial Management, Lviv Polytechnic National University, Lviv, Ukraine E-mail: Mariya.K.Khim@lpnu.ua doi:10.18472/SustDeb.v12n1.2021.38824

\section{ABSTRACT}

The article aims to highlight the latest approaches to the introduction of countries gender budgeting. The authors propose the application of the method of ranking countries based on 4 key indicators related to the gender gap (Economic participation and opportunity, Educational attainment, Health and survival, Political empowerment) of the Global gender gap index and then analyse the result considering the level of socio-economic development of each country. Ten sample countries were randomly chosen. The results of the study confirmed the mutual influence between the gender gap and socio-economic development. The proposed method of ranking countries compared to socio-economic, political and environmental development allows countries with a high value of the gender gap index to offer specific tools to reduce it. The research conducted can help improve existing practices, facilitate initiatives to develop gender parity and further work on geographical and sectoral orientation.

Keywords: Gender gap index. Gender parity. Gender budgeting. Public policy effectiveness. World countries. 


\section{RESUMO}

O objetivo do artigo é destacar as abordagens mais recentes para a introdução do orçamento de gênero dos países. Os autores propõem a aplicação do método de classificação de países com base em 4 indicadores-chave relacionados ao déficit de gênero (Participação econômica e oportunidade, Sucesso educacional, Saúde e sobrevivência e Empoderamento político) do índice de déficit de gênero global e, em seguida, analisam o resultado considerando o nível de desenvolvimento socioeconômico de cada país. Dez países foram escolhidos aleatoriamente como amostra. Os resultados do estudo confirmaram a influência mútua entre déficit de gênero e desenvolvimento socioeconômico. $O$ método proposto de classificar os países pelo índice de déficit de gênero global em comparação com o desenvolvimento socioeconômico permite que os países com alto valor do índice de déficit de gênero ofereçam ferramentas específicas para reduzi-lo. A pesquisa realizada pode servir para aprofundar ainda mais as práticas existentes, facilitar iniciativas para o desenvolvimento da paridade de gênero $e$ continuar a trabalhar na orientação geográfica e setorial.

Palavras-chave: Índice de déficit de gênero. Paridade de gênero. Orçamento de gênero. Eficiência da política de Estado. Países do mundo.

\section{INTRODUCTION}

A focus accompanies sustainable development on gender-related processes related to fundamental individual rights. Although a certain absence of consensus over the societal goals that would count as sustainable development (CONNELLY, 2007), gender equality is considered critical for the success of the 2030 Agenda for Sustainable Development, for which gender equality is fundamental (UN-WOMEN, 2020). Most developed countries are implementing the principles of gender equality to increase the effectiveness of public policies.

Relevant international institutions (United Nations Development Fund for Women, European Economic Commission) take gender into account in fostering sustainable economic development strategies. As a result, the concept of gender responsiveness in budgeting and the implementation of a gender-oriented budgeting strategy was developed (SHARP, 2003).

Sustainable development is not a technical problem that requires new technical means or technologies. This is the problem of changing social relations and forming a society that will not destroy its environment. Sustainable development is not a purely scientific problem. The transition to such a model of development has an ethical meaning. As said in the Our Common Future report: we need to go ahead and get success in elevating sustainable development to a global ethic status. It is a shift in the value orientations of many people. Like any social ideal, the concept of sustainable development is a guide for creating a society that will develop in harmony with nature, combining nature conservation and social development; satisfaction of basic human needs; achieving social equality and social justice; ensuring social self-determination and cultural diversity; maintaining the integrity of ecosystems and the renewal of natural resources, within a holistic approach at national, regional and global levels (WCED, 1987).

Since the World Conference on Women in Beijing in 1995 (UNITED NATIONS, 2001), social equality and social justice within sustainable development debates reinforced the mainstreaming of the gender approach, and this was established as the internationally agreed strategy to promote gender sensitivity in all planned action, law, policies and programs (MEZA, 2017).

Gender policies of austerity and competitiveness have strengthened feminist activism on economic issues. In a context of the dominance of economic criteria in policy design, it is thought that a genderaware budget statement could indicate the extent to which the budget is gender-balanced (ELSON, 1998), facing the effects of a pretended neutrality of public budgets which favours gender inequalities. 
This context called for new approaches to the planning and allocating income and expenditure at the state le. It promoted the idea of the gender impact of economic policies on the political and public debate (HIMMELWEIT, 2002).

Raising awareness of these ideas has sparked discussions about gender budgeting (GB): an increasingly popular strategy to promote gender equality through macroeconomic policies and budgets.

Gender-based budgeting is a strategy to achieve equality between women and men by focusing on the formation and expenditure of public resources. The Council of Europe defines gender budgeting as a gender budget assessment that includes a gender perspective at all levels of the budget process and restructures revenues and expenditures to promote gender equality policies (QUINN, 2009).

This approach to budgeting can improve it in cases where fiscal policy and administrative procedures are structured, taking into account gender inequality (AKHGASIEV, 2018).

The main purpose of gender budgeting is to integrate gender analysis into macroeconomic policies, government expenditures, and revenue proposals to promote gender equality. Based on this, the authors suggest ranking countries based on the Global gender gap index. The research aims to deepen existing practices further, facilitate gender parity, and further work on geographical and sectoral orientation. The expected results of the study are confirmation of the impact of the gender gap on socio-economic development. After all, underestimating the budget's impact on women and men can lead to a result that contradicts the objectives, making it impossible to achieve specific economic indicators, including economic growth, employment, and so on. After all, underestimating the budget's impact on women and men can lead to a result that contradicts the objectives, making it impossible to achieve specific economic indicators, including economic growth, employment, etc.

The purpose of this study is to apply a new method of ranking countries based on 4 key indicators related to the gender gap (Economic participation and opportunity, Educational attainment, Health and survival, Political empowerment) based on the position of the countries on the Gender gap index rank, and then analyse the result considering the level of socio-economic development of each country. The research conducted can help improve existing practices, facilitate initiatives to develop gender parity and further work on geographical and sectoral orientation.

\section{AN OVERVIEW OF THE GENDER BUDGETING}

Current research on gender budgeting worldwide and in Europe focuses on national contexts (KHAN; BURN, 2017; O'HAGAN; KLATZER, 2018). However, the goal of gender budgeting is political - to change macroeconomic policies and economic thinking, making gender and unpaid economies visible (HIMMELWEIT, 2002), which was taken as a basis by researchers. The study of the macroeconomic impact of the gender gap on the socio-economic development of countries and proving the relationship between these categories actualises the presented study.

Quinn (2018) presented an extensive analysis about gender budgeting in European countries: In Austria, Belgium and Spain, the national and regional governments have legislated gender budgeting policies, many have initiated changes in budgetary institutions (including Albania, Belgium, Iceland), while others have adopted the basic concept of marital equality policy together with economic policy (Sweden, Finland, Iceland).

In Austria, gender budgeting has been introduced as part of a broader budget reform process. As part of the reform, gender equality has become one of the four constitutional budgetary principles among transparency, efficiency and an accurate and fair view of the financial position of the Austrian federal government. These characteristics make the Austrian Gender Budgeting Initiative one of the most institutionally sound in Europe and perhaps provide a solid legal basis for improving implementation 
methods to achieve more meaningful results of gender equality in line with socio-economic priorities (KORNIENKO, OSTRISCHENKO, 2016).

In Belgium, the law was introduced to make citizens more committed to gender issues. In the case of Belgium, the law provided for methods and processes for integrating gender equality into all budget processes, collecting and managing gender data, and specifying the goals of gender equality (KORNIENKO, OSTRISCHENKO, 2016). The Belgian initiative differed because it harmonised the ideals of gender equality with a system that covers all aspects of gender equality related to public policy.

Interesting in this area is also the experience of Sweden, where the introduction of gender in budget planning has taken place. At the same time, budget planning considering the gender aspect is fully implemented at the state level in all areas of socio-economic policy (KORNIENKO, OSTRISCHENKO, 2016).

Out of Europe, Budlender (2000) informed that in 1996 the Commonwealth Finance Ministers endorsed a recommendation to initiate a program on engendering budgets encompassing South Africa, Sri Lanka, Barbados and Fiji. According to her, several individual countries have also started to consider gender budgeting and the cross-country Commonwealth program: Namibia, Mozambique, Botswana, Tanzania and Uganda. The end of the 90s could also report a one-day workshop on gender analysis of budgets co-hosted by the British Treasury. All these reported events (the latter British experience, as well as initiatives in Canada and the United States of America, together with those in African countries and the four original movements within Commonwealth) could demonstrate that gender budgeting is of increasing concern worldwide and that it is not something relevant only to developing countries.

In many countries, gender budgeting has been used in difficult economic times to increase efficiency by reviewing the available resource and their more efficient use. Nevertheless, gender budgeting has also a political bias, highlighted by Galizzi, Bassani and Cattaneo (2018). For example, in South Africa, when forming the budget, among other things, racial analysis is carried out, which makes it possible to determine the share of public expenditures for the needs of white men and women and compare them with spending for other racial groups (BUDLENDER, 2005).

Thus, in the current conditions of the country's development, ensuring gender equality is a necessary component of forming a modern civilised socially-oriented society. Gender budgeting is an essential component and a valuable tool for increasing the socio-economic protection of the population, empowering women, and men, ensuring gender equality and developing democratic principles of governance (SHARPE, ALEXANDER, BAILEY, 1999).

Besides, gender budgeting initiatives are in line with the International Labor Organization's approach to gender and development with international commitments on gender equality, such as the Beijing Platform for Action (UNITED NATIONS, 2001), the Convention on the Elimination of All Forms of Discrimination against Women (UNITED NATIONS, 1979), the Millennium Development Goals and the 2030 Agenda (UNITED NATIONS, 2015a, 2015b).

Gender budgeting remains insufficiently covered, a general methodology for monitoring and implementing gender expertise of national and/or local budgets have not been developed, mechanisms for influencing government bodies and strategies for implementing a gender-balanced approach have not been put in place.

\section{MATERIAL AND METHODS}

For the last decade, the global community has come together to address the global gender gap, emphasising the economic aspects of gender parity. It is important to note that there is no single approach or model of gender budgeting. We deal with different actors (government, parliament or NGOs), different tasks, strategies, cultural traditions, levels of executive power, and other political 
situations in other countries. Therefore, several authors have developed analytical tools that can be used in specific cases. The most popular and recognised in the world was the methodological development of gender analysis of the budget policy of the United Nations Development Program and the Secretariat of the British Commonwealth (BUDLENDER; HEWITT, 2003; IVANINA et al., 2016), which offers a methodology for 5 stages of gender budget analysis.

Among other known methods and approaches, it can be mainly (IVANINA et al., 2016, p. 21):

- "5Steps by Debbie Budlender" is one of the earliest initiatives of gender-oriented budgeting in South Africa;

- "Three stages of gender-oriented budgeting by Sheila Quinn". These stages correspond to the entire cycle of processes required to apply the gender dimension as a category of analysis and control within the budget;

- "7 tools of Diana Elson" - a methodology developed by order of the Secretariat of the Commonwealth in 1999;

- "Method 4R" - a tool developed in Sweden in the 1990s and improved in the 2000s;

- "7 steps of gender budgeting" - a methodology proposed as a guide for implementing gender budgeting in Austria. This approach includes 4 phases and 7 steps of gender budget analysis.

The authors of the article analyse the global trends of the gender gap. It was concluded that gender analysis needs to be integrated into macroeconomic policies, government expenditures, and revenue proposals to promote gender equality.

Based on this, the authors suggest applying the method of ranking countries based on the Global gender gap index under new criteria, much more focused on the 4 key indicators related to the gender gap: Economic participation and opportunity, Educational attainment, Health and survival, Political empowerment, and then analyse the result considering the level of socio-economic development of each country. Thus, what is proposed here is to widen the focus to include hierarchical levels (key indicators with and without sub-indicators) and the socio-economic development context.

To do that, a sample of 10 countries from the total 156 countries analysed on the Global Gender Gap Report (WORLD ECONOMIC FORUM, 2021) was chosen.

The 10 countries were randomly drawn considering belonging to different continents, except Ukraine, which was the native country of the authors, and it was of central interest to check data.

Data from each selected country was obtained from individual Country Profiles in the Global Gender Gap Report (WORLD ECONOMIC FORUM, 2021).

The first step of the method involves the calculation of the Global Gender Gap Index for further comparison of countries' index with the original Global Gender Gap Index.

Rating according to key indicators $=\left\{\begin{array}{c}F\left(X_{n}\right) \text { rank, } \\ X n=\sum\left(X_{1} ; X_{2} ; X_{3} ; X_{4}\right), \\ \downarrow F\left(X_{n}\right) \text { rank }=\uparrow S_{E D} .\end{array}\right.$

where, $F\left(x_{n}\right)$ - Global gender-gap index;

$\mathrm{X}_{1}$ - rank of Economic participation and opportunity;

$\mathrm{X}_{2}$ - rank of Educational attainment; 
$X_{3}-$ rank of Health and survival;

$\mathrm{X}_{4}$ - rank of Political empowerment;

$\mathrm{S}_{\mathrm{ED}}$ - socio-economic development.

The index and the rank based on this was generated in two different procedures, the first ones considering only the 4 key indicators with their sub-indicators (the whole system combining both the high hierarchical level indicators and the lower hierarchical level), and the second ones considering only the 4 key indicators without their sub-indicators (the system high hierarchical level only).

Later, countries were compared in terms of gender gap index and socio-economic development.

The comparison of the countries' rank with the socio-economic development is the last step. This step makes it possible to identify countries with a high level of the gender gap and low socio-economic development and further apply measures to implement the policy of budget systems of countries effectively.

\section{RESULTS AND DISCUSSION}

The 10 selected countries were: Azerbaijan, Lebanon, Ukraine, USA, Venezuela, Poland, Australia, United Arab Emirates, Germany, Japan). Their data were all obtained from the individual Country Profiles in the Global Gender Gap Report (WORLD ECONOMIC FORUM, 2021, p. 103, 107, 199, 233, $251,323,381,383,387,393)$.

These countries were ranked according to: a) their original ranking system in the Global Gender Gap Report, and then their relative position about the 10 selected countries; b) the new ranking system considering the 4 key indicators with their sub-indicators; and c) another ranking considering only the 4 key indicators without their sub-indicators (Table 1).

For the last decade, the global community has come together to address the global gender gap, emphasising the economic aspects of gender parity. International experience shows that there are many different approaches to gender budgeting. The essential methods used in the various gender budgeting initiatives are the inclusion of gender aspects in the whole process of public financial management; integration of gender aspects into budgeting based on results and programs; categorisation of budget programs and requirements for gender analysis; a combination of gender budgeting and participatory budgeting; tracking financial allocations to promote women's rights and gender equality; application of standard gender budgeting tools, such as gender policy and budget assessment, separate gender analysis of public expenditure and analysis of tax revenues, as well as gender-sensitive assessment of beneficiaries' needs; gender budgeting; combining gender budgeting with impact assessments. Additionally, Alice Bauman-Dentener, when interviewed by Saito and Nogueira (2017), said that the major constraint to implementing Dublin Principle 3 recognising that Women play a central part in the provision, management, and safeguarding of water has been the lack of funding for Women's Civil Society Groups that work on the water-gender-development interface.

By its economic essence, the assessment of the efficiency of public expenditures allows us to determine how effective and rational are the activities and behaviour of spending units to achieve maximum results from the government (BILYK, 2020). The role of assessing the efficiency of public expenditures is to harmonise the interaction of all sections and components of the budgetary system for the rational use of budget funds and the achievement of relevant significant economic, social and other performance indicators (KARKOVSKA, VASIUNYK, 2016). The use of budget funds through the budget system is carried out mainly with one goal to achieve the goals set in the economy and social policy and improve the environmental situation.

Although most countries have better opportunities to maximise women's economic potential, they cannot profit from their investment in women's education. In addition, very few countries are prepared to meet the challenges and take advantage of the gender parity resulting from the changing nature of work. Top 3 countries with the lowest gender gap are the USA, Germany, Poland (Table 1). Regarding 
the ranking of countries according to key indicators, namely economic participation and opportunity, education, health and survival, political authority, the first three include countries like the USA, Germany, Poland (Table 1).

Therefore, it is essential to create a single platform for cooperation between the state and the private sector to resolve existing gender gaps and to change gender equality in the future: launching international scientific and practical measures to ensure the effective formation and distribution of gender budgets for countries and the exchange of experience with its implementation; development and implementation of programs/projects on the preparation of state and private sectors of the state for gender parity in the further work; providing a quantified commitment from leading organisations to increase labour opportunities and accelerate gender parity in the future; creation of a global knowledge-sharing platform to overcome the gender gap.

While addressing gender budgeting requires a complete process from gender budget analysis to gender mainstreaming throughout the budget process, it is essential to focus on the basic principles of budgeting for research, which is the basis and starting point for further work towards gender equality in resource allocation among different sections of the population.

The principles outlined in the Global Gender Gap Report highlight the approach to overcoming gender gaps based on rational and effective gender budgeting. The distinguishing feature of this Global Gender Gap Index is that it ranks countries according to their proximity to gender equality so that the highest possible score is 1 (gender parity) and the lowest possible score is 0 (imparity), for each index composing criteria (WORLD ECONOMIC FORUM, 2021).

Such a practice has a potentially transformative role, but the most effective is within the framework of a consistent strategy of state budgeting. For such an approach to work, public officials should, in the long term, commit themselves to manage some short-term barriers and trade-offs.

The main difference between this Global Gender Gap Index and the new one presented (Table 1) is that the second one is a positional index, which is more helpful in comparing countries than evaluating gender gaps. That's why all data concerning Index and Subindex, although based on Global Gender Gap Report, they represent the rank position of the country in each index and subindex, and not the gap index initially used to produce the final gender gap index presented by the World Economic Forum (2021).

Table 1 | Ranking of countries by the global gender gap

\begin{tabular}{|c|c|c|c|c|c|c|c|c|c|c|}
\hline $\begin{array}{l}\text { Index/ } \\
\text { Subindex }\end{array}$ & Azerbaijan & Lebanon & Ukraine & $\begin{array}{l}\text { United } \\
\text { Arab } \\
\text { Emirates }\end{array}$ & Venezuela & Poland & Australia & Germany & Japan & USA \\
\hline $\begin{array}{l}\text { * Economic } \\
\text { participation and } \\
\text { opportunity }\end{array}$ & 36 & 139 & 44 & 135 & 112 & 63 & 70 & 62 & 117 & 30 \\
\hline $\begin{array}{l}\text { Labour force } \\
\text { participation }\end{array}$ & 21 & 144 & 71 & 133 & 131 & 81 & 46 & 42 & 68 & 61 \\
\hline $\begin{array}{l}\text { Wages equality } \\
\text { for similar work }\end{array}$ & 17 & 93 & 73 & 12 & 66 & 125 & 68 & 97 & 83 & 74 \\
\hline $\begin{array}{l}\text { Estimated } \\
\text { earned income } \\
\text { (PPP, US \$) }\end{array}$ & 107 & 137 & 82 & 136 & 129 & 65 & 125 & 44 & 101 & 60 \\
\hline $\begin{array}{l}\text { Legislators, } \\
\text { senior officials } \\
\text { and managers }\end{array}$ & 58 & 122 & 31 & 120 & 78 & 28 & 46 & 94 & 139 & 29 \\
\hline $\begin{array}{l}\text { Professional } \\
\text { and technical } \\
\text { workers }\end{array}$ & 1 & 84 & 1 & 148 & 1 & 1 & 1 & 1 & 105 & 1 \\
\hline $\begin{array}{l}\text { * Educational } \\
\text { attainment }\end{array}$ & 62 & 113 & 27 & 89 & 55 & 60 & 1 & 55 & 92 & 36 \\
\hline
\end{tabular}




\begin{tabular}{|c|c|c|c|c|c|c|c|c|c|c|}
\hline $\begin{array}{l}\text { Index/ } \\
\text { Subindex }\end{array}$ & Azerbaijan & Lebanon & Ukraine & $\begin{array}{l}\text { United } \\
\text { Arab } \\
\text { Emirates }\end{array}$ & Venezuela & Poland & Australia & Germany & Japan & USA \\
\hline Literacy rate & 57 & 96 & 50 & 1 & 1 & 72 & 1 & 1 & 1 & 1 \\
\hline $\begin{array}{l}\text { Enrolment } \\
\text { in primary } \\
\text { education }\end{array}$ & 96 & 134 & 1 & 1 & 93 & 94 & 1 & 1 & 1 & 79 \\
\hline $\begin{array}{l}\text { Enrolment } \\
\text { in secondary } \\
\text { education }\end{array}$ & 110 & 1 & 1 & 127 & 1 & 1 & 1 & 113 & 129 & 1 \\
\hline $\begin{array}{l}\text { Enrolment } \\
\text { in tertiary } \\
\text { education }\end{array}$ & 1 & 1 & 1 & - & 1 & 1 & 1 & 1 & 110 & 1 \\
\hline $\begin{array}{l}{ }^{*} \text { Health and } \\
\text { survival }\end{array}$ & 154 & 82 & 41 & 130 & 1 & 1 & 99 & 75 & 65 & 87 \\
\hline Sex ratio at birth & 155 & 1 & 127 & 1 & 1 & 1 & 1 & 1 & 1 & 1 \\
\hline $\begin{array}{l}\text { Healthy life } \\
\text { expectancy }\end{array}$ & 59 & 95 & 1 & 138 & 1 & 1 & 110 & 83 & 72 & 99 \\
\hline $\begin{array}{l}\text { * Political } \\
\text { empowerment }\end{array}$ & 141 & 112 & 103 & 24 & 77 & 89 & 54 & 10 & 147 & 37 \\
\hline $\begin{array}{l}\text { Women in } \\
\text { Parliament }\end{array}$ & 111 & 150 & 98 & 1 & 89 & 53 & 44 & 43 & 140 & 60 \\
\hline $\begin{array}{l}\text { Women in } \\
\text { ministerial posts }\end{array}$ & 148 & 43 & 110 & 62 & 48 & 142 & 64 & 23 & 126 & 14 \\
\hline $\begin{array}{l}\text { Years with the } \\
\text { female head } \\
\text { state (last } 50 \\
\text { years) }\end{array}$ & 76 & 76 & 44 & 76 & 76 & 37 & 43 & 6 & 76 & 76 \\
\hline $\begin{array}{l}\text { Sum key } \\
\text { index+subindex }\end{array}$ & 1410 & 1623 & 906 & 1334 & 961 & 915 & 776 & 752 & 1573 & 747 \\
\hline Sum key index & 393 & 446 & 215 & 378 & 245 & 213 & 224 & 202 & 421 & 190 \\
\hline $\begin{array}{l}\text { Gender gap } \\
\text { index }\end{array}$ & 0,688 & 0,638 & 0,714 & 0,716 & 0,699 & 0,713 & 0,731 & 0,796 & 0,656 & 0,763 \\
\hline $\begin{array}{l}\text { Rank Gender } \\
\text { gap index report } \\
\text { (global rank) }\end{array}$ & 100 & 132 & 74 & 72 & 91 & 75 & 50 & 11 & 120 & 30 \\
\hline $\begin{array}{l}\text { Rank Gender } \\
\text { gap index report } \\
\text { (regional rank) }\end{array}$ & 23 & 6 & 14 & 2 & 24 & 15 & 4 & 7 & 18 & 16 \\
\hline $\begin{array}{l}\text { Rank gender } \\
\text { gap index report } \\
\text { (sample) }\end{array}$ & 8 & 10 & 5 & 4 & 7 & 6 & 3 & 1 & 9 & 2 \\
\hline $\begin{array}{l}\text { Rank } \\
\text { index+subindex }\end{array}$ & 8 & 10 & 5 & 1 & 7 & 6 & 4 & 3 & 9 & 2 \\
\hline Rank index & 8 & 10 & 4 & 7 & 6 & 3 & 5 & 2 & 9 & 1 \\
\hline
\end{tabular}

Source: Calculated by the authors based on Global Gender Gap Report 2021 (WORLD ECONOMIC FORUM, 2021, p. 103, 107, $199,233,251,323,381,383,387,393)$

This method is appropriate because when considering countries in the overall ranking, it is pretty challenging to analyse the gender gap of one country about the total number of countries due to a large amount of data.

Table 2 | presents the comparison of the countries based on the new gender gap index and the socio-economic development Indicators. 


\begin{tabular}{|c|c|c|c|c|c|c|c|c|c|c|}
\hline Country & $\begin{array}{c}\text { The } \\
\text { efficiency } \\
\text { of public } \\
\text { expenditures }\end{array}$ & $\begin{array}{c}G D P \\
\text { (billion, \$) }\end{array}$ & $\begin{array}{c}\text { Value of } \\
\text { population } \\
\text { (women/ } \\
\text { men) }\end{array}$ & $\begin{array}{c}\text { Gender } \\
\text { gap }\end{array}$ & $\begin{array}{c}\text { Economic } \\
\text { participation } \\
\text { and ability }\end{array}$ & $\begin{array}{c}\text { Education } \\
\text { level }\end{array}$ & $\begin{array}{l}\text { Health } \\
\text { and } \\
\text { survival }\end{array}$ & $\begin{array}{l}\text { Rating } \\
\text { according } \\
\text { to the } \\
\text { gender gap }\end{array}$ & $\begin{array}{l}\text { Rating } \\
\text { according } \\
\text { to key } \\
\text { indicators }\end{array}$ & $\begin{array}{c}\text { Rating } \\
\text { according to } \\
\text { Efficiency of } \\
\text { public }\end{array}$ \\
\hline Germany & 5,4 & 3000.78 & 1,02 & 0,796 & 0,706 & 0,997 & 0,972 & 1 & 2 & 3 \\
\hline USA & 5,9 & 20000.81 & 1,02 & 0,763 & 0,754 & 1 & 0,97 & 2 & 1 & 2 \\
\hline Australia & 3,6 & 1000.34 & 1,01 & 0,731 & 0,7 & 1 & 0,968 & 3 & 5 & 6 \\
\hline UAE & 6,2 & 353.9 & 0,44 & 0,716 & 0,51 & 0,987 & 0,963 & 4 & 7 & 1 \\
\hline Ukraine & 2,4 & 142.3 & 1,16 & 0,714 & 0,732 & 1 & 0,978 & 5 & 4 & 8 \\
\hline Poland & 3,2 & 580.9 & 1,06 & 0,713 & 0,705 & 0,996 & 0,98 & 6 & 3 & 7 \\
\hline Venezuela & 1,1 & 48.61 & 1,03 & 0,699 & 0,617 & 0,998 & 0,98 & 7 & 6 & 10 \\
\hline Azerbaijan & 4,7 & 41.67 & 0,98 & 0,68 & 0,748 & 0,99 & 0,939 & 8 & 8 & 4 \\
\hline Japan & 4,1 & 4000.91 & 1,05 & 0,656 & 0,604 & 0,983 & 0,973 & 9 & 9 & 5 \\
\hline Lebanon & 1,8 & 18.73 & 0,99 & 0,638 & 0,487 & 0,964 & 0,97 & 10 & 10 & 9 \\
\hline
\end{tabular}

* Note: Calculated by the authors based on 2021 World Economic Forum data (GLOBAL GENDER GAP REPORT, 2021)

Determining the rating by such ranking methods allows determining the rating of one country about others on common grounds (which are on the same level): on the level of socio-economic development, on a territorial basis, for the population etc. The point is that those countries that meet these criteria are compared at the same level, or countries at different levels of development are compared. Through such comparisons, it is possible to assess the gender gap between countries and its role in socio-economic development. This is not done by the Global Gender Gap Report (WORLD ECONOMIC FORUM, 2021), which testifies that their gender gap index measures gender-based gaps in access to resources and opportunities in countries and not the actual levels of the available resources and opportunities in those countries, because they want to disassociate the Global Gender Gap Index from countries' levels of development (WORLD ECONOMIC FORUM, 2021, p. 72).

Research shows that countries taking steps to increase gender access to education, health, employment and credit, thereby reducing the gender gap in access to economic opportunities, point to accelerating economic development and poverty reduction. Financial liberalisation has also improved economic opportunities for women, in part through greater access to credit. As a result, the growth of macroeconomic indicators such as GDP, public spending efficiency, economic participation conditions, education levels and health indicators is essential.

The issue of responding to gender inequality concerns the social or psychological aspect and the economic one. Studies in 67 developing countries have shown that, on average, one in five men disagree that women have jobs outside the home, even if they are qualified. Inequality also persists in the legislation. At least one law in 155 countries restricts women's economic rights (RHODES; HARVEY; PARVEZ, 2017).

Significantly, achieving women's employment will boost the global economy by 5.8 trillion \$, which will provide tax revenue growth of 1.5 trillion $\$$. This increase will expand the emerging market opportunities (990 billion \$) and developed countries (530 billion \$) in North African countries, Arab countries and South Asian countries, as it is in these regions that the most significant gaps in participation in the workforce of women and men (INTERNATIONAL LABOUR OFFICE, 2017). Level of participation in the workforce and breaks in participation in 2017 - estimated data. According to recent data, gender inequality in developing countries is estimated at 9 trillion $\$$ a year - an amount that will benefit not only women but also raise the purchasing power of different communities and provide a massive impetus for the development of the economy as a whole (OXFAM INTERNATIONAL, 2017). Why the majority of the world's poor are women). Empowering women requires the creation of decent 
jobs for them, good opportunities for fair pay, and the increasing role of women in decision-making in power. With these targets in mind, the goal is to achieve full and productive employment, and decent work, for all women and men by 2030 (UNITED NATIONS, 2017b). This is vital for reducing poverty and achieving broader sustainable development goals.

Gender budgeting at the state level. The introduction of gender budgeting at the central government level is important, since budget decisions on incomes and expenditures are taken at their level.

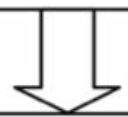

Gender budgeting at the regional and local levels. The proximity of regional and local authorities to everyday life means that there is a potential for more direct responses to the needs of women and men when it comes to state policies and services. At these levels, there is great potential for using gender budgeting methods among the local population.

Figure 1 | Levels of gender budgeting*

*Information is taken from authors' sources

Gender budgeting is a strategy for achieving equality between women and men, focusing on collecting and spending public resources. Gender budgeting is an approach that can improve when fiscal policy and administrative procedures are structured to address gender inequality. The introduction of gender budgeting will help save public money, considering the different needs of women and men (NIRAS, 2020). Gender budgeting can be applied to any budget system at all levels of government (Figure 1).

The effectiveness of gender budgeting involves implementing a political commitment in line with the technical capacity to implement gender policy (Figure 2). Management decision-making should focus on ensuring gender mainstreaming in the planning and budgeting processes and the income and expenditure of the state budget for the benefit of women and men alike. A good example can be found in Ukraine, where MAMA-86, an environmental, women's and social justice organisation, has lobbied and worked with the Ukraine government successfully supporting the design of a legal framework on water and health issues, including the National Environment and Health Action Plan (2001), the Law on Drinking water (2002), the program on "Drinking Water of Ukraine" (2005), and the national targets for the Protocol on Water and Health (2011) (BOUMAN-DENTENER, 2017).

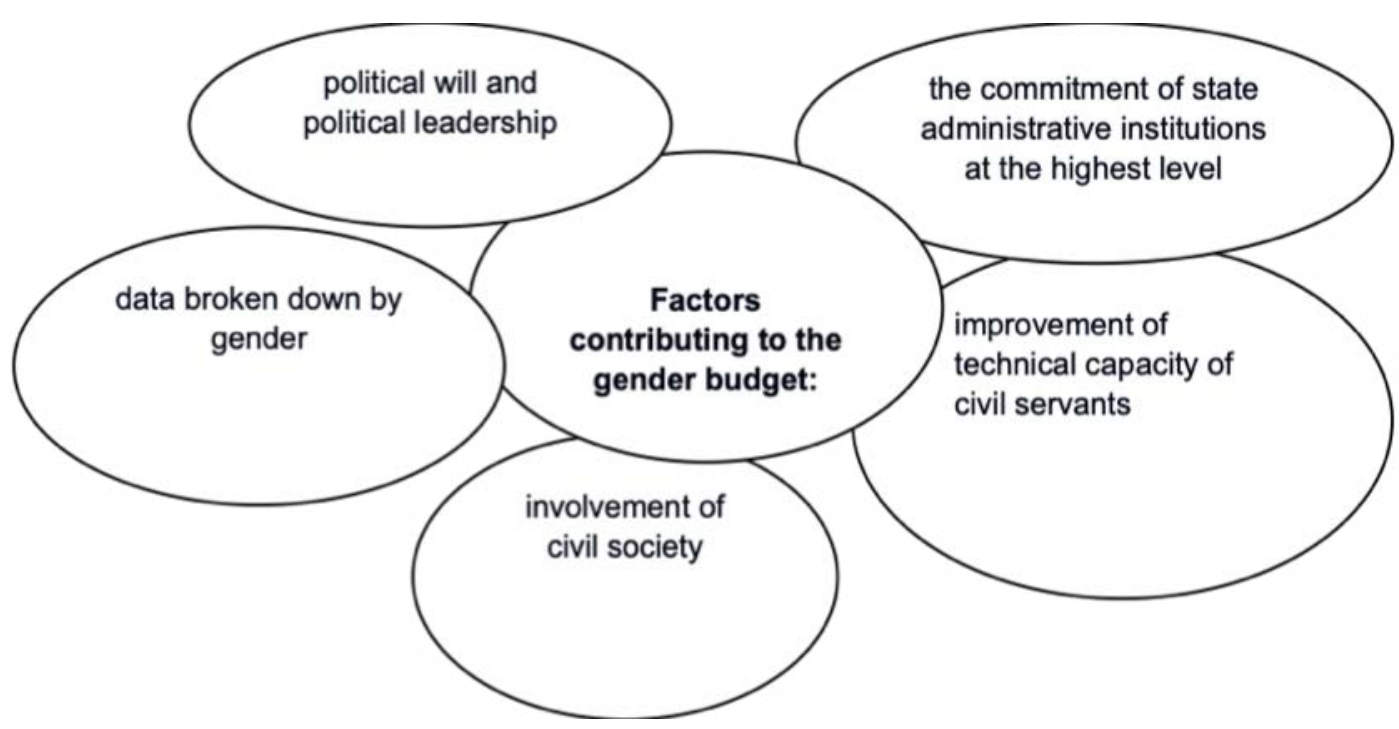


Figure 2 | Factors of gender budgeting promoting*

*Information is taken from authors' sources.

Political will and leadership are based on an active political stance to promote gender equality and ensure development. Features of the political will factor are:

- increased awareness of key actors such as higher authorities, political parties, regional and local assemblies, and advisory bodies;

- public support for gender-sensitive budgets;

- Policy recommendations on gender budgeting;

- Gender mainstreaming in the budget and related policies.

Equally important is the commitment of top-level state administrative institutions, which is characterised by the implementation of clear instructions on the performance and follow-up of civil servants in fulfilling their gender equality commitments.

Improving the technical capacity of civil servants to implement gender budgeting policies and recommendations should be coupled with the political will of the civil service and the pursuit of gender equality to ensure that ambitions and competencies are matched.

Civil society plays a crucial role in ensuring that the state is held accountable for meeting international and national commitments to gender equality. It can also play a vital role in linking the state and society and facilitating participation in budgetary processes.

Gender-disaggregated data is a favourable factor in gender budgeting. Therefore, a reliable statistical system and management information systems in government institutions, structures and research institutes are critical.

In gender budgeting, the principles underlying the high-quality budget process play an essential role (Figure 3). Current public financial management standards include principles such as performance orientation, transparency, accountability, etc.

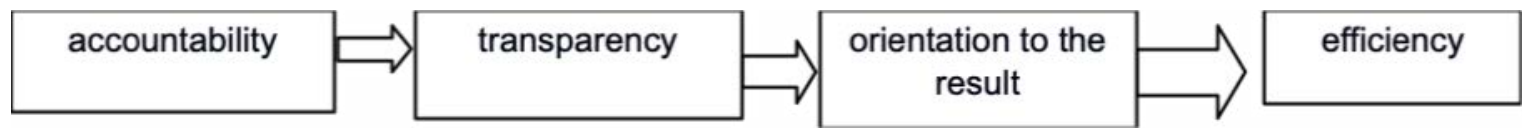

\section{Figure 3 | Principles for implementing gender budgeting*}

*Information is taken from authors' sources.

Gender budgeting analyses the impact of budgets on women and men, which is also considered an essential part of monitoring how the budget works towards achieving gender equality goals in the country. Implementing the gender budget will make the state accountable for its gender policy commitments, civil society and the media and play an essential role in monitoring and ensuring government accountability for their budgets.

Gender budgeting should be taken into account for transparency. Increasing participation in the budget process can be achieved by introducing public consultation practices and participation in budget preparation or public involvement in budget monitoring. 
Performance-based budgeting brings strategic planning and public finance closer together, linking policy goals more closely to budgets. This is done by defining goals, objectives and activities and creating a monitoring system based on performance indicators to measure progress. A proper, results-oriented approach only happens when gender budgeting is integrated into budgeting for implementation. Gender budgeting helps improve information on the potentially different situations and needs of women and men and the impact of the allocation and impact of resources on women and men. Thus, gender budgeting provides the basis for better and more informed decision-making. This, in turn, contributes to more efficient use of public funds and increased control over the system of budget formation and distribution.

International experience shows that there are many different approaches to gender budgeting. The essential methods used in various gender budgeting initiatives are:

- gender mainstreaming in the entire public finance management process;

- gender mainstreaming in results- and program-based budgeting;

- categorisation of budget programs and requirements for gender analysis;

- combining gender budgeting and participatory budgeting;

- tracking financial allocations to promote women's rights and gender equality;

- the use of standard gender budgeting tools such as gender policy and budget estimation, gender-disaggregated public expenditure and tax revenue analysis, and gender needs assessment of beneficiaries;

- gender budgeting;

- combining gender budgeting with impact assessments.

Based on the study of gender budgeting results, the following conclusion can be drawn: identifying gender gaps (gender-discrimination, negative trends) in meeting the needs and interests of women and men and restoring parity. An analysis of the detection of gender gaps in different countries was carried out (Figure 4), confirming the authors' hypothesis that the increase or decrease of gender gaps is directly proportional to the level of budgeting costs.

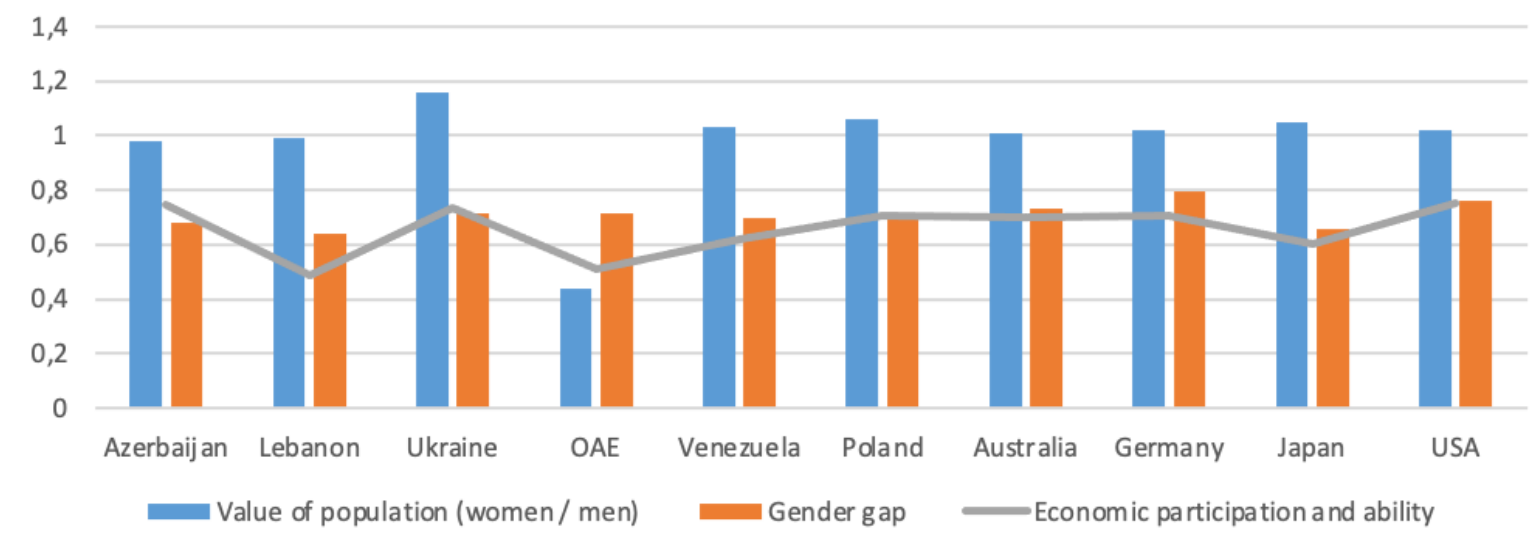

Figure 4 | Dynamics of Gender Parity Change in the World in 2021*

*Information is taken from authors' sources. 
To ensure decent work, including adequate income, secure contracts and safe working conditions, governments and businesses should consider the quality and security of women's economic opportunities. This requires:

- an assessment of current labour standards and wage rates to ensure that the legislative labour standards cover homeworkers, migrant workers and informally employed workers;

- legislative solutions to the problem of violence and discrimination in the workplace;

- consulting with employees and trade unions on raising the minimum wage as compared to the living wage;

- provide concerted efforts to close the pay gap, including ensuring equal pay for work of equal value and promoting decent work for women;

- repeal laws that discriminate women's economic equality and introduce legislation and a legal framework that supports women's rights;

- promoting positive social norms and attitudes towards women's work, restoring the balance of power in the household, at the local, national and international levels;

- providing women with access to more paid positions, as well as improving access to education and training;

- promoting transparent ways for policies that encourage employers to hire and train lowskilled employees;

- recognise, reduce, and redistribute unpaid homework;

- governments should invest in state services and infrastructures that reduce and redistribute unpaid care work, including general free public health, social assistance, child care, water and sanitation, and education services;

- governments and international financial institutions should incorporate unpaid care work within their economic development strategies;

- governments and the business community should recognise the high responsibility of women for unpaid care work and provide flexible working hours and paid parental leave;

- governments should be encouraged to redistribute unpaid care work based on policies that encourage men to do their fair share. These include flexible work schedules and parental leave for both parents. Social rules on the distribution of responsibilities of men and women for care work, for example, through advertising or public campaigns;

- governments and international institutions should collect more accurate data on the distribution of unpaid care work and its contribution to the economy as a whole.

Also, governments need to increase fiscal space for women's economic empowerment through a progressive scale and gender-sensitive tax policies, help overcome tax evasion by large corporations and individuals and use this extra income to invest in state services. 
As part of the scientific search for managing social risks innovative mechanisms, we note that gender differences are differences not only in gender but also in specific needs due to mental, social, ethnic, racial, religious differences.

However, considering current trends, it can be argued that today the application of gender-based budgeting cannot cover the entire budget process due to financial constraints. Thus, in 2020 there are 930 gendersensitive passports, compared to 325 in 2019 (MINISTRY OF FINANCE OF UKRAINE, 2021). It is also essential that the existing constraints on program funding require the development of a methodology. Taking into account the above, the stages of gender-oriented budgeting have been improved (Table 3 ).

Table 3 | The process of improving the gender-oriented budgeting stages implementation in terms of sustainable development

\begin{tabular}{|c|c|c|}
\hline \multirow{3}{*}{$\begin{array}{l}\text { 1. Assessment of the initial situation } \\
\text { and opportunities for work in a } \\
\text { particular area }\end{array}$} & $\begin{array}{c}\text { 1.1 Stakeholder analysis. } \\
\text { Identification of target groups and } \\
\text { beneficiaries }\end{array}$ & $\begin{array}{l}\text { It is necessary to apply SWOT } \\
\text { analysis, which will consider } \\
\text { the strengths and weaknesses, } \\
\text { opportunities and threats within } \\
\text { a particular local community or a } \\
\text { specific program. }\end{array}$ \\
\hline & $\begin{array}{l}\text { 1.2 Assessment of organisational } \\
\text { and personnel prerequisites for } \\
\text { implementation }\end{array}$ & $\begin{array}{l}\text { It is necessary to add the } \\
\text { information policy analysis in } \\
\text { gender-oriented budgeting } \\
\text { construction (by surveying the } \\
\text { population, analysing information in } \\
\text { the media, etc.) }\end{array}$ \\
\hline & $\begin{array}{l}1.3 \text { Compilation of a "gender } \\
\text { profile." }\end{array}$ & $\begin{array}{l}\text { It is necessary to add a qualitative } \\
\text { data retrospective analysis in a } \\
\text { particular area (in the course of } \\
\text { decentralisation, it is essential to } \\
\text { structure mental, geographical, } \\
\text { religious, ethnic features). }\end{array}$ \\
\hline \multirow{4}{*}{$\begin{array}{l}\text { 2. Conducting gender budget } \\
\text { analysis (industries/programs, } \\
\text { activities) according to gender } \\
\text { differences }\end{array}$} & 2.1 Estimation of services cost & $\begin{array}{c}\text { It is necessary to structure people } \\
\text { by age. }\end{array}$ \\
\hline & 2.2 Estimation of personnel costs & $\begin{array}{l}\text { Similarly, it is necessary to analyse } \\
\text { the age structure of staff }\end{array}$ \\
\hline & $\begin{array}{l}2.3 \text { Industry/program funding } \\
\text { comparative analysis by years }\end{array}$ & $\begin{array}{l}\text { Application of comparative analysis } \\
\text { with other regions, programs, } \\
\text { countries and construction of trends }\end{array}$ \\
\hline & $\begin{array}{l}\text { 2.4 Evaluating the services } \\
\text { effectiveness }\end{array}$ & $\begin{array}{c}\text { Application of service efficiency } \\
\text { qualitative evaluation (surveys, } \\
\text { questionnaires) }\end{array}$ \\
\hline \multirow{2}{*}{$\begin{array}{l}\text { 3. Identification of gender-specific } \\
\text { issues, goals and objectives }\end{array}$} & $\begin{array}{l}\text { 3.1. Analysis of existing facts of } \\
\text { gender inequality, as well as policy } \\
\text { decisions and measures that } \\
\text { exacerbate such inequality }\end{array}$ & $\begin{array}{l}\text { It is advisable to analyse the } \\
\text { information policy regarding a } \\
\text { specific program or territorial unit }\end{array}$ \\
\hline & $\begin{array}{l}\text { 3.2 Formation of gender-specific } \\
\text { goals and objectives of budget } \\
\text { policy aimed at solving gender- } \\
\text { specific problems }\end{array}$ & $\begin{array}{l}\text { It is necessary to identify the } \\
\text { preconditions for gender inequality }\end{array}$ \\
\hline $\begin{array}{l}\text { 4. Formation of gender-sensitive } \\
\text { budget proposals }\end{array}$ & $\begin{array}{l}4.1 \text { Identify measures within the } \\
\text { sector/program budget that will } \\
\text { contribute to gender equality }\end{array}$ & $\begin{array}{l}\text { In the conditions of limited financial } \\
\text { resources, it is necessary to apply } \\
\text { A / B - testing that will considerably } \\
\text { simplify the implementation of all } \\
\text { previous stages }\end{array}$ \\
\hline
\end{tabular}


These steps are necessary for the initial implementation of gender-based budgeting. But in the future, it is proposed to use A / B testing to select gender-sensitive programs. Also, the use of this method is crucial in the conditions of Covid-19 because it is based on the use of digital technologies. A / B testing offers a very systematic way to determine the effectiveness of any process. This test is based on the application of marketing technologies in the digital economy. Most marketing efforts are aimed at increasing traffic. In particular, in the case of expanding the application of the gender approach, we can consider the efforts of its supporters through the prism of marketing and position it as an effective way to minimise social risk and improve the socio-economic situation in the country. Focusing on digital space requires flexibility in gender-based budgeting and traffic expansion. However, because purchasing traffic is complex and costly, it becomes a top priority to offer the best experience to stakeholders who visit gender-based budgeting websites. This will help them achieve their goals and perform the conversion in the fastest and most efficient way. A structured A / B testing program can make marketing efforts more profitable by identifying the most critical problem areas that need to be optimised and applied to gender budgeting. In the practice of commercial enterprises, the application of A / B testing moves from independent activity, which was limited to the frequency of once a month, to a more structured and continuous, which should always be carried out through a clearly defined process. Usually, in A / B testing, only two possible programs or directions are used, but the variety of potential programs should be considered.

It is necessary to use digital technologies to define and optimise processes in conditions of quarantine restrictions. A / B Testing (also known as Separate Testing) is a website optimisation technique that sends half of the users to one version of a page and the other half to another and viewing web analytics to see which one is more efficient. However, through this testing, it is possible to determine the effectiveness of applying gender-sensitive scenarios in the public management system of social risks. The application of A / B testing is summarised in Figure 5.

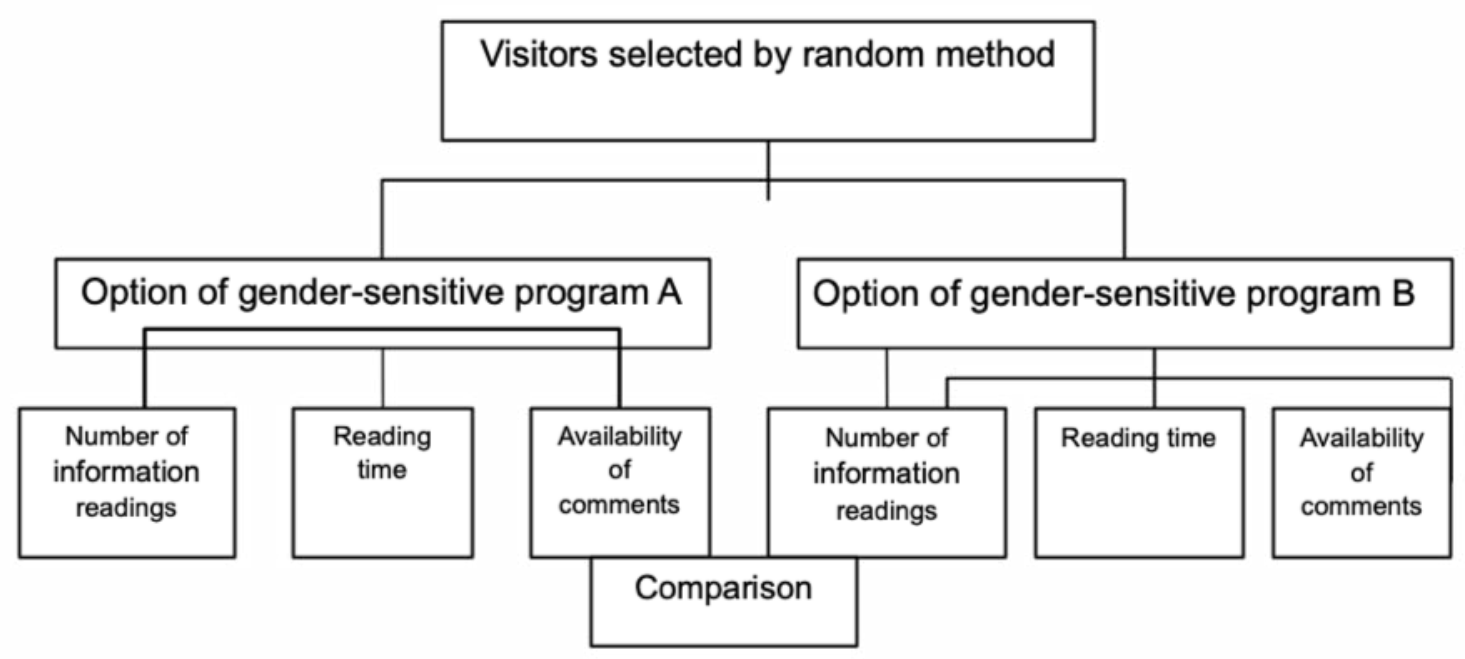

Figure 5 | Generalized scheme of A / B-testing application for gender-sensitive programs construction

Google Analytics and Google Optimize offer one of the best data collection and A / B testing solutions. It allows getting almost everything you need for free. The Google Analytics 360 suite includes 360 optimisations and provides a wide range of tools in the free version. However, it is essential to have a professional who knows how to set up advanced tracking. This is the main disadvantage of Google: you need to know the platform and how to get the most out of it. It will require appropriate technical training. This type of testing will significantly simplify identifying gender-sensitive budgets or those 
areas that need the most intervention or are the least gender-sensitive. Table 4 projects the steps for implementing A / B testing for gender budgeting.

Table 4 | Proposed stages of A / B testing implementation for gender budgeting

\begin{tabular}{|c|c|}
\hline Stage & Description \\
\hline Testing goals & $\begin{array}{l}\text { Increasing readership, increasing subscriptions, increasing visitors' time on the website, or } \\
\text { speeding up viewing of videos and other materials using social sharing }\end{array}$ \\
\hline Measurement & Testing program planning \\
\hline Setting priorities & $\begin{array}{l}\text { Prioritisation helps to sort several hypotheses scientifically. At this point, you should get } \\
\text { website data, visitor data and clearly define the goals, taking into account the lag in the } \\
\text { first stage. }\end{array}$ \\
\hline \multirow{3}{*}{ Terms } & $\begin{array}{l}\text { Precise time measurements of testing, the randomness of the study (random approach), } \\
\text { continuity of tests (ie sampling should be constant). }\end{array}$ \\
\hline & Considering those options that did not work. \\
\hline & The sample (hypothesis) must have a causal relationship. \\
\hline \multirow{2}{*}{$\begin{array}{l}\text { The concretisation of } \\
\text { testing measurements }\end{array}$} & $\begin{array}{c}\text { Specific social button, which is available in public institutions (eg Center for Administrative } \\
\text { Services). }\end{array}$ \\
\hline & Testing of registration methods by e-mail \\
\hline $\begin{array}{l}\text { Compiling a testing } \\
\text { calendar }\end{array}$ & $\begin{array}{c}\text { An effective optimisation program will always have two parts: planning and setting } \\
\text { priorities }\end{array}$ \\
\hline \multirow[t]{2}{*}{ Making changes } & Analysis of all the results, changes. \\
\hline & Choosing the best option for a gender-sensitive social program. \\
\hline \multirow[t]{2}{*}{ Efficiency } & A more efficient process of analysing gender data. \\
\hline & Raising public awareness. \\
\hline
\end{tabular}

Reducing gender inequality can improve macroeconomic indicators. Recognising that gender differences are harmful and state budgets are not gender-neutral means that gender considerations need to be included in the budgeting process. Although gender budgeting initiatives can take many forms, their most important purpose is to influence the budgeting process and help policymakers focus on how public policy can help reduce gender inequalities and improve economic performance.

It is essential for the study and development of gender parity:

- understanding current gaps, recognising bias, setting goals, and reporting on the benefits of promoting gender parity in organisations or structures;

- making changes in the design of programs/budgets, namely overcoming gaps, such as payments, parental leave, productivity reviews, hiring processes, mentoring, sponsorship, training in security and governance, etc;

- expanding initiatives beyond the boundaries of specific areas and promoting change in industries, communities, value chains and the wider society. 


\section{CONCLUSIONS}

The results of the study confirmed the impact of the gender gap on sustainable development. By reducing the gender gap, countries can achieve the UN's sustainable development goals. The proposed method of ranking countries by the index of the global gender gap allows countries with a high value of the gender gap index to offer specific tools to reduce it. The authors explored gender budgeting as a critical tool.

The proposed method of ranking countries involves the implementation of public administration decisions. In particular: the detection of gender gaps; distribution of public finances according to gender differences; based on A/B testing to identify gender-sensitive budgets that need the most adjustment; conducting a qualitative assessment of the need for specific measures by comparing socio-economic development indicators.

Consequently, governments should adopt gender budgeting approaches that systematically include women's organisations and civil society to ensure proper control and fully assess the impact of economic policies on women and girls. They should support the training of organisations and women in this area and improve the collection of relevant statistics.

The systematic introduction of gender budgeting can contribute to improving the quality of public and local finance management; improving economic efficiency and effectiveness; improving the allocation of financial resources; promoting effective management and quality of services; encouraging the achievement of goals of gender equality and human development; monitoring achieving political purposes, in particular ensuring gender equality; increase transparency, accountability and public participation in planning and budget implementation. The gender budget contributes to improving the quality of services for the population because there are clear guidelines for the specific consumer; increasing the pace of economic development and reducing poverty; efficient use of resources; allows taking attention to a broader range of issues, the solution of which will create equal opportunities for all members of the community and ensure sustainable development. This approach makes the budget efficient, fair and transparent.

\section{ACKNOWLEDGEMENTS}

The authors would like to thank the Editor-in-Chief and the anonymous reviewers for their constructive comments and invaluable suggestions to the earlier versions of the manuscript.

\section{REFERENCES}

AKHGASIEV, I. Gender-oriented Budgeting as a Democratic Practice during a Selfgovernment Reform: ukrainian experience. Business Ethics and Leadership, v. 2, n. 3, p. 21-33, 2018. Available at: https://doi.org/10.21272/ bel.2(3).21-33.2018. Access on: Nov. 01, 2021.

BILYK, O. Strategy for improving the quality of life in countries with economies in transition. International Journal of Management (IJM), v. 11, n. 4, p. 523-531, 2020.

BOUMAN-DENTENER, A. M. Women's agency in water governance: lessons from the water and health nexus in Armenia and Ukraine. Sustainability in Debate, v. 8, n. 3, p. 64-74, 2017. Available at: http://dx.doi.org/10.18472/ SustDeb.v8n3.2017.26587. Accessed in: 25 Sept. 2021.

BUDLENDER, D. The Political Economy of Women's Budgets in the South. World Development, v. 28, n. 7, p. 1365-1378, 2000. Available at: https://doi.org/10.1016/S0305-750X(00)00016-4. Accessed in: 28 Sept. 2021.

BUDLENDER, D. Gender budgets. Bratislava: UN Development Program, 2005. 
BUDLENDER, D.; HEWITT, G. Engendering Budgets: a practitioners' guide to understanding and implementing genderresponsive budgets. London: Commonwealth Secretariat, 2003. Available at: https://www.internationalbudget.org/ wp-content/uploads/2011/01/Engendering_Budgets_final_doc.pdf. Accessed in: 28 Sept. 2021.

CONNELLY, S. Mapping sustainable development as a contested concept. Local Environment, v. 12, n. 3, p. 259278, 2007. Available at: https://doi.org/10.1080/13549830601183289. Accessed in: 28 Sept. 2021.

ELSON, D. Integrating gender issues into national budgetary policies and procedures: some policy options. Journal of International Development, v. 10, n. 7, p. 929-941, 1998. Available at: https://doi.org/10.1002/(SICI)10991328(1998110)10:7\%3C929::AID-JID563\%3E3.0.CO;2-5. Accessed in: 12 Jul. 2021.

GALIZZI, G.; BASSANI, G. V.; CATTANEO, C. Adoption of Gender-Responsive Budgeting (GRB) by an Italian Municipality. Administrative Sciences, v. 8, n. 4, article 68, 2018. Available at: https://doi.org/10.3390/ admsci8040068. Accessed in: 12 Jul. 2021.

HIMMELWEIT, S. Making the hidden economy visible: arguments for analyzing the gender impact of economic policy. Feminist Economics, v. 8, n. 1, p. 49-70, 2002. Available at: https://doi.org/10.1080/13545700110104864. Accessed in: 12 Jul. 2020.

INTERNATIONAL LABOUR OFFICE. World Employment and Social Outlook: trends for women 2017. Geneva: ILO, 2017 Available at: https://www.ilo.org/global/research/global-reports/weso/trends-for-women2017/lang-en/index.htm. Accessed in: 23 Jul. 2022.

IVANINA, T. et al. Gender-oriented budgeting in Ukraine: theory and practice. Kiev: United Nations Women in Ukraine and the Friedrich Ebert Foundation Representation in Ukraine, 2016, 92 p.

KARKOVSKA, V.; VASIUNYK, P. Employee's life cycle and its influence on company`s personnel security. Actual Problems of Economics, v. 181, n. 7, p. 290-297, 2016. Available at: http://www.scopus.com/inward/record. url?eid=2-s2.0-84978734652\&partnerID=MN8TOARS. Accessed in: 08 Jul. 2020.

KHAN, Z.; BURN, N. Financing for gender equality. Realizing women's rights through gender. London: Palgrave Macmillan, 2017. Available at: https://genderandsecurity.org/projects-resources/research/financinggender-equality-realising-womens-rights-through-gender. Accessed in: 02 Jul. 2021.

KORNIENKO, N.; OSTRISCHENKO, Y. Gender component of state budget policy. Bulletin of KNTEU, n. 1, p. 97-108, 2016.

MEZA, L. E. R. Incorporando la perspectiva de género en la gestion del agua: lecciones aprendidas desde Chiapas, México. Sustainability in Debate, v. 8, n. 3, p. 37-50, 2017. Available at: https://doi.org/10.18472/SustDeb. v8n3.2017.26474. Accessed in: 26 Sept. 2021.

MINISTRY OF FINANCE OF UKRAINE. Gender-oriented budgeting at local level. Available at: https://mof.gov.ua/ uk/283-genderno-oriientovane_biudzhetuvannia_na_mistsevomu_rivni. Accessed in: 26 Sept. 2021.

NIRAS. Gender-Responsive Budgeting Project in Ukraine: results and reflections 2013-2020. Stockholm: Niras. 2020. Available at: https://www.niras.com/media/p1qocqbj/grb-book-final.pdf. Accessed in: 28 Jul. 2021.

O'HAGAN, A.; KLATZER, E. Gender budgeting in Europe. Developments and challenges. London: Palgrave Macmillan, 2017.

OXFAM INTERNATIONAL. Why the majority of world's poor are women. Oxford: Oxfam international. 2 March 2017. Available at: https://www.oxfam.org/en/why-majority-worlds-poor-are-women. Accessed in: 12 Jul. 2018.

QUINN, S. Gender budgeting: practical implementation, Handbook. Strasbourg: Council of Europe, Directorate General of Human Rights and Legal Affairs, April 2009.

QUINN, S. Europe. In: KOLOVICH, L. L. (Ed.) Fiscal Policies and Gender Equality. USA: International Monetary Fund. Washington: International Monetary Fund, 2017. p. 53-105. Available at: https://www.elibrary.imf.org/ view/books/071/23551-9781513590363-en/ch04.xml. Access on: 17, Nov. 2021. 
RHODES, F.; HARVEY, R.; PARVEZ, A. An economy that works for women. Oxfam briefing paper. Oxford: Oxfam International. March 2017. Available at: https://www.oxfamindia.org/sites/default/files/bp-an-economy-thatworks-for-women-020317-en.pdf. Access on: Nov. 17, 2021.

SAITO, C. H.; NOGUEIRA, D. Dialogues on mainstreaming gender dimensions into water issues. Sustainability in Debate, v. 8, n. 3, p. 16-21, 2017. Available at: http://dx.doi.org/10.18472/SustDeb.v8n3.2017.27318. Accessed in: 26 Oct. 2021.

SHARP, R. Budgeting for equity: gender budget initiatives within a framework of performance oriented budgeting. New York: Unifem, 2003.

SHARPE, W. C.; ALEXANDER, G. J.; BAILEY, J. W. Investments. Englewood Cliffs, USA: Prentice Hall, 1999.

UNITED NATIONS. Convention on the Elimination of All Forms of Discrimination against Women and the Optional Protocol to the Convention on the Elimination of All Forms of Discrimination against Women. New York: United Nations, 1979.

UNITED NATIONS. Beijing Declaration and Platform for Action with the Beijing+5 Political Declaration and Outcome Document. New York: Department of Public Information, United Nations, 2001. Available at: https:// beijing20.unwomen.org/ /media/headquarters/attachments/sections/csw/pfa_e_final_web.pdf. Accessed in: 25 Sept. 2021.

UNITED NATIONS. The Millennium Development Goals Report 2015 curated by the Center for Latin American and Caribbean Studies at Michigan State University. New York: United Nations, 2015a.

UNITED NATIONS. Transforming our world: the 2030 Agenda for Sustainable Development. New York: United Nations General Assembly A/RES/70/1. 25 September 2015b. Available at: https://www.un.org/en/development/ desa/population/migration/generalassembly/docs/globalcompact/A_RES_70_1_E.pdf. Accessed in: 18 Nov. 2021.

UN-WOMEN. Gender Equality: women's rights in review 25 years after Beijing. New York: UN-Women, 2020.

WCED. Our Common Future. World Commission on Environment and Development. Oxford: Oxford University Press, 1987.

WORLD ECONOMIC FORUM. Global Gender Gap Report 2021. Geneva, Switzerland: World Economic Forum, 2021. Available at: https://www3.weforum.org/docs/WEF_GGGR_2021.pdf. Accessed in: 04 Jul. 2021. 